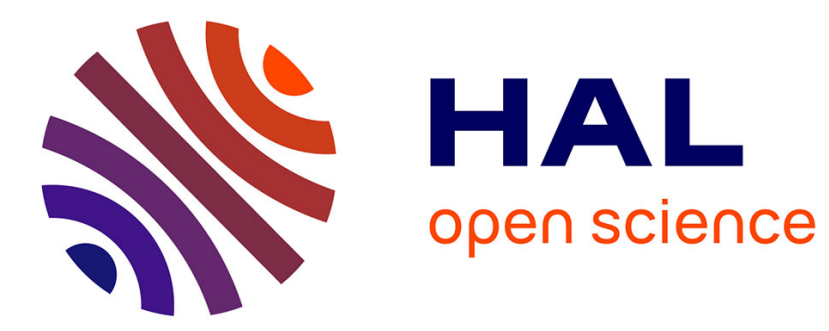

\title{
A portrait of Carnap as a young philosopher
}

Pierre Wagner

\section{- To cite this version:}

Pierre Wagner. A portrait of Carnap as a young philosopher. Metascience, 2021, 10.1007/s11016021-00630-7 . hal-03154874

\section{HAL Id: hal-03154874 \\ https://hal.science/hal-03154874}

Submitted on 28 May 2021

HAL is a multi-disciplinary open access archive for the deposit and dissemination of scientific research documents, whether they are published or not. The documents may come from teaching and research institutions in France or abroad, or from public or private research centers.
L'archive ouverte pluridisciplinaire HAL, est destinée au dépôt et à la diffusion de documents scientifiques de niveau recherche, publiés ou non, émanant des établissements d'enseignement et de recherche français ou étrangers, des laboratoires publics ou privés. 


\section{A portrait of Carnap as a young philosopher}

This is a preprint of an article published in Metascience. The final authenticated version is available online at: https://doi.org/[insert DOI]" 10.1007/s11016-021-00630-7

A. W. Carus, Michael Friedman, Wolfgang Kienzler, Alan Richardson, and Sven Schlotte (eds.) : Rudolf Carnap: Early writings : The collected works of Rudolf Carnap, Volume 1. New York: Oxford University Press, 2019. 528 pp, £74 HB

Pierre Wagner

pierre.wagner@univ-paris1.fr

IHPST (Institut d'histoire et de philosophie des sciences et des techniques)

Université Paris 1 Panthéon-Sorbonne

Paris, France

Carnap is known as one of the major past figures of analytic philosophy of science, philosophy of logic, and philosophy of language, and as one of the main representatives of logical empiricism. In the last decades, he has been the focus of numerous studies by scholars who have strived and succeeded in painting a more reliable portrait than the one that has long prevailed. Despite all these efforts, however, more than half a century after his death, his thought is still poorly known by the philosophical audience and large parts of his writings remain difficult to access. The publication of the Collected Works of Rudolf Carnap aims to provide a scientific edition of his publications, to fill important editorial gaps, and to pave the way for a better and more general understanding of his philosophy. This ambitious project, placed under the editorial responsibility of Richard Creath, will consist of a series of fifteen volumes bringing together all the texts Carnap authorized for publication during his lifetime, along with an English translation placed opposite the original texts when these were written in a different language. Carnap's unpublished notes, diary, manuscripts, and correspondence are not part of the project, which will already require years of collaborative work by a team of specialists as it stands.

The first volume of this major undertaking brings together Carnap's early writings, originally published in German from 1918 through 1926. This volume reveals a significantly different Carnap from the famous author of The Logical Construction of the World and of the other classics of analytic philosophy he wrote later. The Carnap of the Early Writings turns out to be neither a representative of logical empiricism, nor a philosopher of language, nor a critic of metaphysics, nor yet a reader of Wittgenstein's Tractatus. This Carnap does not conceive any metalinguistic approach to theories, he does not pursue any quest for a characterization of analyticity, he is not interested in studying and comparing logical frameworks, nor is he working on confirmation or on modal or inductive logic. The reader who is not already acquainted with Carnap's first publications will discover a political writer; a thinker deeply influenced by neo-Kantianism, ready to acknowledge the existence of a priori synthetic judgements; a reader of Husserlian phenomenology, who at some time regarded intuition of essences as a source of knowledge; and a philosopher-physicist very much 
concerned with methodological questions raised by the general theory of science. All the texts in Volume 1 of the $C W R C$ were written at a time when Carnap was not yet in Vienna and not yet a member of the Vienna Circle.

The ambition of this volume is threefold. The first goal is to produce a flawless scientific edition of the original version of Carnap's first publications along with their translation into English, precise information on the various editions, the original pagination for convenient reference (indicated in the inside margin), and a detailed record of the minor corrections made to the text by the editors. The typesetting and the material quality of the edition are excellent.

Because reading some of the pieces included in this volume turns out to be quite demanding, the second aim of the editors is to provide historical, philosophical and scientific information useful for a thorough understanding of the author's thought. The reader thus benefits from clarifications and in-depth commentaries by some of the best contemporary Carnap scholars or by specialists in the sometimes technically difficult issues dealt with in the texts. Reference is made to Carnap's unpublished papers, diary, drafts of the texts, lectures, and marginal notes written by him in his own copies of the publications, all these being also extensively cited. While each text is enriched with editorial notes, two of them are the subject of more abundant commentaries than the others: Carnap's dissertation on Space, which is supplemented by thirty-six pages of illuminating scholarly notes by Michael Friedman, and the 1925 article "On the Dependence of the Properties of Space on those of Time", followed by a most useful commentary by David B. Malament, which sheds light on the technical presuppositions of the text and translates them into the language of contemporary physics. A chronology of Carnap's life is also provided at the beginning of the volume, and both a general bibliography and an index of names at the end.

A glance at the table of contents of Carnap's Early Writings may give the impression that the volume consists of a heterogeneous set of papers and issues: a newspaper article on the constitution of a transnational organization at the end of the First World War (1918), the review of a book by Hugo Dingler on conventionalism and the laws of nature (1921), Carnap's PhD dissertation on space (1922), three papers in the field of the philosophy of physics (1923, 1924, and 1925), and a booklet intended for a wider public devoted to the formation of physical concepts (1926). The third overall goal of the editors of this volume is to correct the erroneous impression of a somewhat heteroclite collection of papers and to show that these writings actually "fall quite neatly" into groups which "dovetail surprisingly closely" (xxiii). The nineteen-page introduction, written by A. W. Carus and M. Friedman, is certainly not too long for such an ambitious project. What the reader finds in it is an overview of Carnap's conceptions and plans at the time he wrote the papers gathered in the volume; an account of the mutual relationships of these papers; an analysis of the strongest influences that various authors exerted on Carnap's thought; and a detailed story of his evolving views in the post-war period, by two of the best contemporary specialists in the thought of the young Carnap, based on a collection of writings and notes which extends far beyond the published papers. Illuminating as this reading of the volume background might be, a good deal of trust is required from the reader because, for quite understandable reasons, the authors chose to leave 
almost all references to secondary literature out of the story they tell in this rich, pithy, and dense introduction.

The story begins with "Carnap's utopian conception of the role of knowledge and ideas in society" (xxiii), which is actually represented by less than three pages in the whole volume, although this is "the tip of a much larger iceberg" (ibid.) and a key for understanding Carnap's later projects and views. Especially important is the idea that for Carnap a rational systematization of knowledge is "a prerequisite for the rational organization of a society" (xxvii). Such an "engineering attitude" inherited from the Enlightenment through Comte and Ostwald offers a reading grid for later works and in particular for several of the texts included in Early Writings. These can be interpreted as contributions to the search for a coherent and logically grounded system of knowledge whose underlying motivation, rarely made explicit, is a rational coordination of the activities in a society. Hence, the questions that Carnap strives to answer in several of the papers in this volume are as follows: What is the epistemic link between sense experience and mathematical formalism? How should we distinguish empirical facts, general laws, and mere stipulations? How can we realize the project of a general system of all concepts?

The general introduction also offers illuminating hints - but less than detailed answers, obviously for lack of space - to some of the key questions the reader needs to keep in mind, while reading the whole volume, in order to recognize in Carnap's philosophical moves the successive steps he takes towards his goal of a rational system of knowledge. Why was Carnap dissatisfied with strict empiricism? How did he move from an examination of specific scientific questions to a reflection pertaining to the general theory of science? What precisely was the role of phenomenology in the evolution of his thought? What is the philosophical justification for the space of intuition which is central in the 1922 dissertation, as opposed to formal and physical spaces? How did Russell's use of abstraction principles enable Carnap to overcome the neo-Kantian influences still prevalent in this dissertation? What function does Carnap attribute to the axiomatic method in the theory of science? What is the role of the structural approach of the objects of knowledge in the project of a rational reconstruction of science?

With this volume in hand, the reader benefits from easy access to the original papers, supplemented by a faithful English translation, a rich critical apparatus, enlightening editorial notes, and an original and well-informed suggested interpretation. But why bother reading Carnap's Early Writings in the first place? In addition to the obvious historical value of the whole volume, each piece has its own, sometimes major, specific interest. Furthermore, the reader finds here a striking confirmation of what Carnap studies have, over the last few decades, revealed: namely that the most common views about Carnap's thinking were in need of serious revision and that a renewed reading of his works discloses original, rational, and clear thinking that is most enlightening and useful for numerous issues debated in contemporary philosophy. 